\title{
A Qualitative Inquiry on Academic Social Identity A Case Study on Students of Department of Psychology Universitas Pembangunan Jaya
}

\author{
Gita Widya Laksmini Soerjoatmodjo ${ }^{1}$ \\ ${ }^{1}$ Department of Psychology, Universitas Pembangunan Jaya \\ South Tangerang, Banten 15413, Indonesia \\ gita.soerjoatmodjo@upj.ac.id \\ *gita.soerjoatmodjo@upj.ac.id
}

Received 3 May 2020, Revised 26 September 2020, Accepted 28 September 2020

\begin{abstract}
What does being a student of Psychology in Universitas Pembangunan Jaya (UPJ) mean to you? This question was given to 33 students-cum-participants of this research. The background was that academic social identity - defined as how individuals identify to their academic institutions and/or subject areas they undertake during the time spent throughout their educational process - is key to their achievements. The objective was to understand the academic social identity of UPJ Department of Psychology students, particularly those who took Qualitative Research Method course in 2019/2020 Academic Year, to better understand their trajectories. This writing used qualitative research method with youth participatory action approach, applying photovoice as data collecting method, which produced visual and textual data analyzed from interpretative phenomenological perspective. The result showed that their academic social identity comprised of the following stages: understanding what Psychology is, their own personal and non-personal reasons to choose this discipline and then understanding their roles as students - both in Department Psychology and in UPJ. Discussion touched upon the stage that seemed to be particularly painstaking: understanding their roles as students - opening doors to provide student service supports to ensure smoother transition. It was concluded that academic social identity is a never-ending process.
\end{abstract}

Keywords: Academic social identity, Youth participatory action research, Photovoice, Interpretative phenomenological analysis, Psychology

\begin{abstract}
Abstrak - Apa makna menjadi mahasiswa Psikologi UPJ bagimu? Pertanyaan ini diberikan kepada 33 mahasiswa partisipan penelitian ini. Latar belakang penelitian ini adalah pemahaman bahwa identitas sosial akademik - yakni bagaimana seseorang mengidentifikasikan diri dengan institusi akademik dan/atau disiplin ilmu yang mereka pelajari selama menempuh proses belajar - merupakan hal yang mempengaruhi prestasi akademik. Tujuan penelitian ini adalah memotret gambaran identitas sosial akademik pada mahasiswa Program Studi (Prodi) Psikologi UPJ, khususnya mereka yang mengambil mata kuliah Metode Penelitian Kualitatif pada Tahun Akademik 2019/2020, guna memahami trajektori yang mereka lalui. Menggunakan metode kualitatif, penelitian ini memakai pendekatan aksi partisipatif kaum muda dengan photovoice untuk mengumpulkan data visual dan tekstual yang kemudian dianalisis dengan sudut pandang fenomenologis interpretatif. Hasil penelitian ini menunjukkan bahwa identitas sosial akademik mereka terbagi ke dalam sejumlah tahap berikut: memahami apa itu Psikologi, memahami alasan pribadi dan non-pribadi mereka mengapa memilih disiplin ilmu ini, kemudian memahami peran mereka sebagai mahasiswa - baik sebagai mahasiswa Prodi Psikologi maupun mahasiswa UPJ. Diskusi tulisan ini menyinggung tahap yang tampaknya paling berat: memahami peran mereka sebagai mahasiswa - yang membuka kemungkinan akan perlunya layanan dukungan mahasiswa agar transisi di tahap ini lebih mudah mereka jalani. Dapat disimpulkan bahwa identitas sosial akademik merupakan proses pencarian tiada henti.
\end{abstract}

Kata Kunci: Identitas sosial akademik, Penelitian aksi partisipatif kaum muda, Photovoice, Analisis fenomenologis interpretatif, Psikologi 


\section{INTRODUCTION}

The background of this research is as follow. Based on existing literature, the nature of higher education is that it has three aims: (a) to prepare, train and impart knowledge and 'marketable skills' to students for their intended profession or career; (b) to socialize the new generation into academia and the professional word, and (c) to develop self-direction, critical thinking and the capacity to understand (Smyth, Mavor, Platow \& Grace, 2017).

Throughout their endeavors to pursue these aims, their academic social identity - which is part of the university students' social identification with their discipline - is in fact a powerful tool in yielding substantive academic outcomes - due to the fact that it promotes their own deep approach to learning (Bliuic, Goodyear \& Ellis, 2017).

Moreover students' attempt to meet psychological needs may particularly be well suited to their university contexts - as their transitions from a highly structured environment in high schools to a relatively unregulated university environment allows them to meet their need for autonomy - reflected in their independent discovery and choices of a range of learning opportunities (Greenaway, Amiot, Louis \& Bentley, 2017).

Hence, McGeogh (2017) concluded that academic social identity has a strong relationship with achievement. For undergraduate students, this identity is more than simply belonging, but that of internalization of their subject identities, more likely to occur during transition periods, particularly in the early months of entry into higher education. Furthermore McGeogh (2017) also suggested policy implication for institutional arrangement of student support services - the purpose that this article also follows its recommendation.

Literature review of this phenomenon of the above-mentioned problem can be extracted into the following arguments

Academic social identity was defined as how individuals identify to the academic institution and/or subject area that they undertake during the time spent throughout their educational process. (McGeogh, 2017). The trajectory of emulating this academic social identity was rather a private affair.

Barnett (2006) argued that the being of the students is achieved through a process of becoming, as individuals attempt to answer the core question: what was it to become a student? It was arguably important to make sense of this interaction of the private and public realms of student experience of being and becoming.

Furthermore, Bliuc, Ellis, Goodyear and Hendres (2011) found out that the emphasis of social and psychological aspects of the learning experience could be used to improve our understanding of how and why students varied in the quality of their learning.
To do so, we need a view of what it means to be students and what would it take to make that positive for the individuals themselves - so we can better support them by influencing their sense of purpose (Henderson, Bathmaker \& Stevenson, 2018). Hence, the theoretical basis of this article is to find out more on the process of being and becoming - on what it is to become a university student - by focusing on the meaning making process of their academic social identity throughout its trajectory.

Previous studies of the above-mentioned phenomenon particularly on higher education contexts are as follow. Maunder, et. al. (2013) found that students held internal images about their university as formed through cultural experience, which were later on used to shape their expectation and to create meaning out of those experiences. These social relationship were particularly pivotal for them, and the development of peer groups assisted their adjustments into relatively unfamiliar environments.

Moreover, undergoing this transition contributes to their personal changes of identity. Permana, et.al. (2017) argued further that adopting the new identity as university students could necessarily expose them to psychological crises. McGeogh (2017) who explored the academic social identity in undergraduate Psychology students captured how academic social identity changed, developed and impacted through the time of transition. Meanwhile Sari, Tarsono and Kurniadewi (2016), who focused also on Department of Psychology undergraduate students, documented that their academic social identity status significantly influenced their future orientation.

To conclude, studies have shown that understanding academic social identity of university students - to be able to answer "what does it means to me to be a university student?" - could impact numerous dimensions of their life, not only in academic realms but also social and psychological arenas; not only in the present time but also their future.

This research aims to address the following problem: what does it means to be university students? The purpose of this study is to understand the academic social identity of university students to better understand their trajectory.

Compared to the previous studies, this article deliberately offers a zoom-in focus on Universitas Pembangunan Jaya (UPJ) as a particular context, with Department of Psychology as key settings, in examining the meaning making process. This specific aim is the gap this research attempts to fill in - since a literature review identifies that research regarding academic social identity of UPJ students still does not exist.

This should also be taken into consideration that the temporal, contextual background of this article is the $8^{\text {th }}$ anniversary, or Sewindu in Sanskrit language, of the university itself. In Javanese tradition, this 
moment is marked by introspective reflection of its existence and identity (Damono, Mardianto \& Mardiyanto, 1996).

The significance of contextual underpinnings in Sewindu UPJ are the features separating this articles from the previous studies undertaken on the subject matters - with the hope that this qualitative inquiry would be beneficial for UPJ as part of its contemplative pondering of its subsistence and congruence.

Such reflection is relevant to youth participatory action research adopted in the development of this article. The method highlighted the potential of youth research to transform learning experiences into rewarding personal growth which propelled students on to lifelong exploration (Mirra, Garcia \& Morrel, 2016). It is hoped that their voices would contribute to the in-depth reflection. This participatory approach is clearly established by the fact that this writing was in fact part of the learning process of Qualitative Research Method course, a compulsory unit in the curriculum of Department of Psychology UPJ. In a sense, students participating in the making of this paper allow their personal experience to be used in the course, to then empower their juniors - to both develop their own academic social identity as well as to endure the Qualitative Research Method course.

The attempt to answer this particular research question is systematically presented in sections of this article - comprising of introduction, literature review, research methods, results and discussions and finally, conclusion.

\section{METHODS}

This writing used qualitative research method as it attempted to capture detailed description of the overall process being studied (Shawn, 1999). Youth participatory action research was selected as strategy of inquiry, as the researcher-cum-lecturer assumed the role of facilitator by provide guidance to subject-cumparticipants in order to build participants' confidence and independence with the hope that this approach would equip them with lifelong skills beyond this project (Mathikithel \& Wood, 2019).

Photovoice was used as data collection technique which allowed individuals to actively participate in the research process by giving them a chance to take and use their words and pictures to tell their stories and have their voices heard (Palibroda, et. al., 2009).

Data analysis is done using interpretative phenomenology analysis - which involves detailed examination of exploration of personal experience, concerned with perception or account of objects or events, emphasizes that research is a dynamic process with an active role into the private world (Eathough \& Smith, 2017).

Research subjects-cum-participants were $335^{\text {th }}$ semester students of Department of Psychology UPJ. On one hand, the selection of this subject was partly because this writing followed the direction taken by
McGeogh (2017) as she focused on the third year students; and on the other hand, it was due the fact that these students took Qualitative Research Method course on their odd semester in 2019/2020 academic year.

By deliberately involving them as research subjects, not only did they have hand-on experience to understand key concepts of qualitative research method but also they had the exposure which allowed them to develop their capacities to take on their own group research projects. Prior to participating in this research, they received lectures and reviewed academic journals in Psychology using qualitative methods and discussed participatory action research and photovoice, then finally all of them filled out and signed informed consent which adhered the guidelines set in the 2010 Code of Ethics of Himpunan Psikologi Indonesia (HIMPSI, 2010).

Questions used for this research was as follow: what does being a student of Psychology in Universitas Pembangunan Jaya means to you? In order to answer this question, these students as research subject-participants were given one-week to take or use personal pictures which could be used to answer the questions, completed it on the next weeks with photo captions explaining details regarding the photos and their own personal reflections on why they chose the photos and what they expected others to see.

Throughout August-September 2019, they collected visual and textual data using their own personal gadgets such as camera phones and/or photos from personal collection including those posted in their social media Instagram accounts. Throughout October 2019, data collected in cloud-based OneDrive used as the main repository of textual and visual data were examined collaboratively. Researcher-lecturer guided the students who served as research subjectsparticipants to carry out their analysis - which later on be submitted as course assignment. Results and discussions of this research are elaborated in the following section.

\section{RESULTS AND DISCUSSION}

In this sections, pictures, photo captions and personal reflection displayed are chosen on the basis of clarity in the expression articulated by research subjects-participants to they describe their academic social identity as a Psychology students in UPJ.

Besides the breadth of representation, the selection also considers aesthetic qualities of both visual and textual data provided. The author of this article took the liberty of translating the caption submitted in Bahasa Indonesia by maintaining the essence of the textual words.

It should be taken into consideration that permissions to use textual and visual data belonging to the students had been secured in the informed consents. These are the findings - conveyed in both visual and textual data gathered from the students. 
Figure 1. Photo submitted by Laila Midori

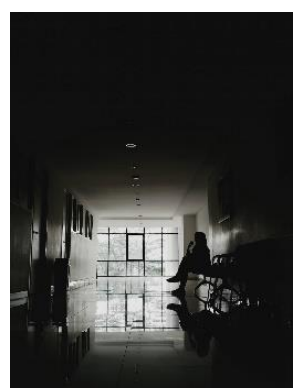

Text submitted by Laila Midori: As a Psychology student, I often emerge in my own stream of consciousness, questioning myself: why I am this way or that way? Psychology helps me find myself, understand myself better and make peace with myself. As a Psychology student in UPJ, indeed I experience darkness and light, joy and sadness as well as tears and laughter. This picture was taken by my best friends and I feel content and comfortable with this photo. Even though I am by myself, I have friends who support me along the way. Darkness does not always symbolizes despair, being alone does not always means being lonely.

This particular picture and its caption explores personal sentiments offered by the research subject in dealing with her own personal inquiry of finding out about herself.

Figure 2. Photo submitted by Yunita Fitriani

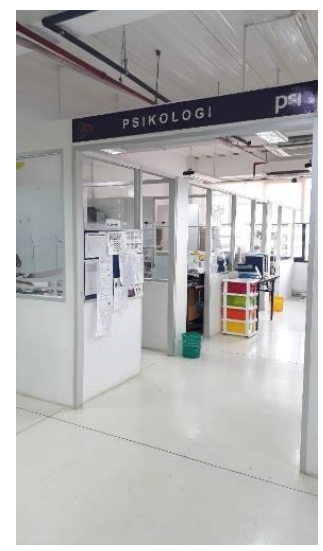

Text submitted by Yunita Fitriani: This room witnessed how I came here, again and again and again, for my academic assignments and organizational responsibilities. I practically spend most of my time in the last two years of my life in the Department of Psychology.

This pictorial and textual information provided by the research subject showcases the notion of dharma or another word, duty - as reflected the key words used: assignment and responsibilities, and, implicitly personal sacrifice and commitment.
Figure 3. Photo submitted by Muhammad Rizky

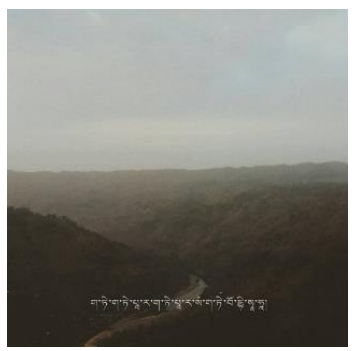

Text submitted by Muhammad Rizky: This picture - captured as I hiked in Yogyakarta - reminds me of the mixture of both exhaustion and excitement. As a Psychology student, I am prone to be experience fatigue with all the demands and therefore self-care is indeed essential to maintain physical and mental health.

The particular set opens door for a more vulnerable outlook in his exploration - that finding out the meaning of being a Psychology students as well as carrying out all the work entails is often tiring.

These set of three highlights that in order for these research subject to find the answer of the question: "What does being a student of Psychology in Universitas Pembangunan Jaya means to you?" - the question brings them to understand what Psychology is and to understand their very own personal reasons as well as their ups and downs..

Figure 4. Photo submitted by Safira Prabandari

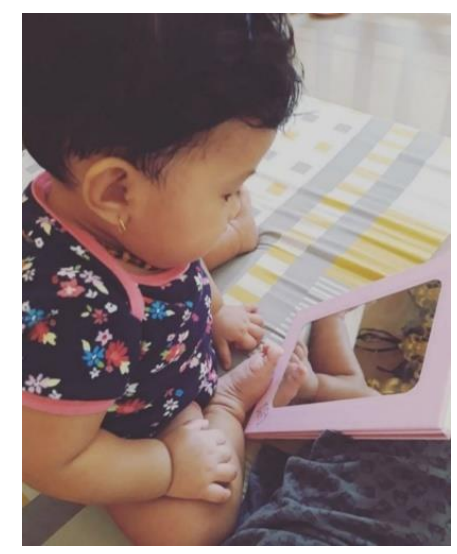

Text submitted by Safira Prabandari: We use psychology to educate others and to reflect about ourselves. For students, Psychology helps us deal with our own personal problems.

The analysis of both the picture and the caption elaborates that this research subject zooms in on the meaning of being a Psychology student is to heal others and themselves as well - highlighting the double-sword perspective of professional and personal development. 
Figure 5. Photo submitted by Karina Rahayu

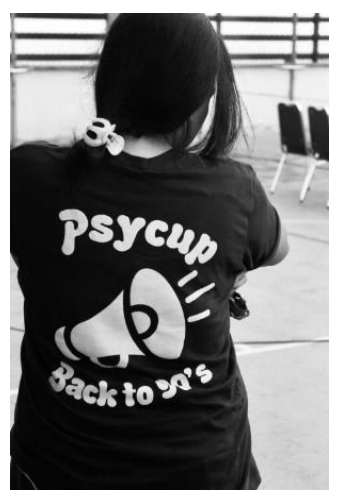

Text submitted by Karina Rahayu: This was taken when I joined a student committee of an official Department of Psychology event in which I learned a lot. Psychology can be learned outside the classrooms, from real life experiences and not just text books.

The analysis of both the picture and the caption highlights that this research subject believes that the meaning of being a Psychology student is to apply it in both inside and outside of the classroom - turning the attention to another double-sword standpoint of theoretical and practical application of the disciplines.

Figure 6. Photo submitted by Nurul Indah Ramadhanti

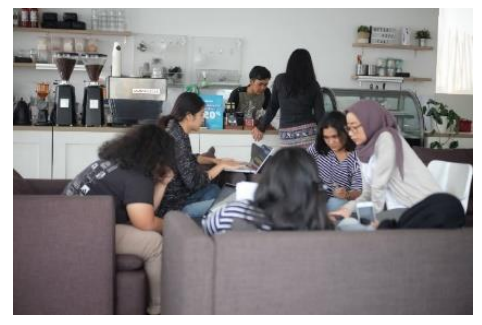

Text submitted by Nurul Indah Ramadhanti: This picture describes the life of myself and my friends, supporting each other, so we can achieve our goals. I feel blessed for all the social supports I got from my friends. We have our togetherness, even though in this moment, we actually worked on our own separate projects.

The picture and the words also exhibits another flip-flop outlook: being with themselves and with friends, working as individuals as well as a group, being independent but also dependent, being alone yet together.

The last three sets pictures and captions turn the spotlight from the personal to the social aspect of the journey to find out what being a student of Psychology in Universitas Pembangunan Jaya means to them. This endeavor unearths their social reasons. A different set of tone is offered by the next evidence.
Figure 7. Photo submitted by Dinda Ayu Dwi Innesia

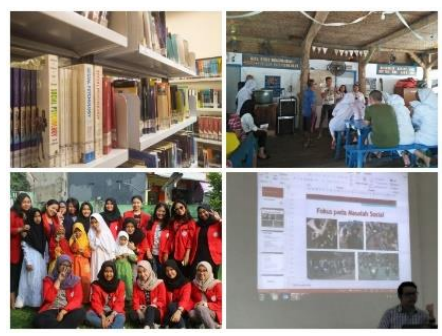

Text submitted by Dinda Ayu Dwi Innesia: This collage of pictures represents how Psychology students have to be active in taking part in various activities. Psychology pushes us to go to extra miles because I need to understand all the theories and knowledge in order to better understand my clients in the future. This pictures show that Psychology students are highly resilient and they just never ever give up.

The analysis of information provided by this research subject through the picture and caption goes slightly further to the roles of being a Psychology student, rather than personal and social reasons - that the role of learning today is for serving others tomorrow, so becoming a Psychology students means building her own short and long-term advantage.

Figure 8. Photo submitted by Juli Sarah Harahap

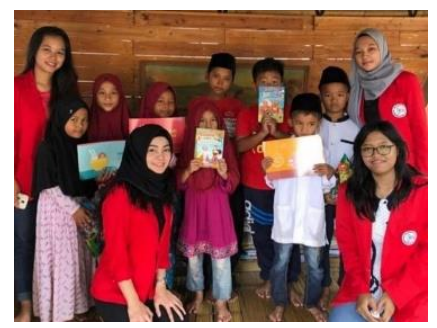

Text submitted by Juli Sarah Harahap: The picture was taken when I shared what I learned in Psychology in an exciting story telling session with kids from Roemah Tawon (Beehive) along with my friends. I would like to show others that applying Psychology to others is such a fun experience and I would like to inspire others to do the same thing as well.

The picture and caption analysis reveals that this research gives the center stage to the meaning of being a Psychology student - to be inspired and to inspire others. This set now enters the realm of roles rather than reasons, personal or social ones.

Note that these two sets highlight the formal attire worn by the students: red alma-mater jackets. This symbolizes that they now emulate the attribute of UPJ as the university where they learn as part of their own 
personal identity. This tone is also accentuated on the last picture and its caption, as follow:

Figure 9. Photo submitted by Athaya Dwinda Zakiah

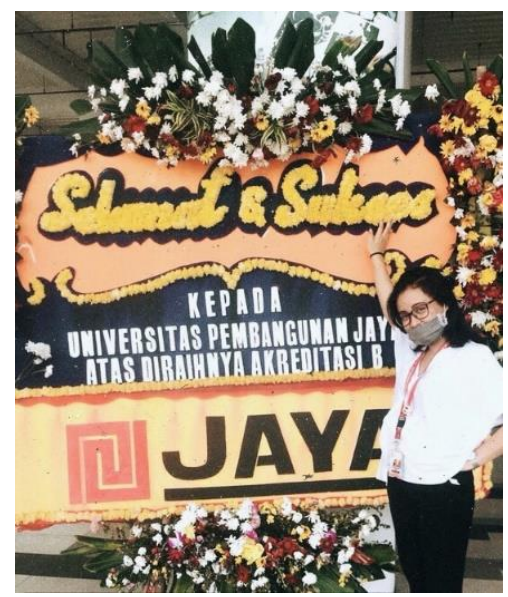

Text submitted by Athaya Dwinda Zakiah: This picture represents how as a Psychology student of UPJ, I am proud and touched by UPJ achievement. Now the general public would never underestimate UPJ anymore.

This analysis shows that the last set highlights the fact that the research subject does not only identify herself clearly as a Psychology students in UPJ, but she also takes pride of UPJ's achievement as her own - by using the keywords of being proud and touched.

As the selected pictures, captions and personal reflections represent key findings, here are the overview extracted from all 33 pictures, 33 photo captions and 33 personal reflections submitted as visual and textual data of this research.

This is represented by Figure 10 .

Figure 10. Academic Social Identity

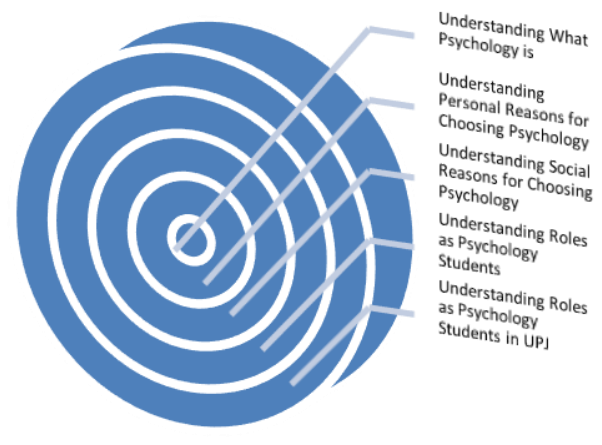

Based on the analysis of the visual and textual data collected, the key essence of academic social identity lies on the core of understanding what psychology is. Research subjects-participants express their academic social identity by elaborating their own understandings on the definition of psychology and how psychology is learned both inside and outside of the walls of the classrooms. It seems that their academic social identity is determine first and foremost by the definition of Psychology as an academic discipline and its roles on addressing their personal and social issues.

The next layer of their academic social identity is couched on their personal reasons why they choose Psychology. They build their academic social identity by using Psychology as instruments or tools to understand themselves first, then to understand others later. Personal queries into their own private realms seem to be the key driving forces of the process of establishing their academic social identity.

The layer that comes after it is their social reasons - to educate others on how to resolve their personal problems as well as to serve the needs of their socalled future clients. It seems that they are aware of the social dimension of Psychology in helping others in dealing with their personal struggles in order to become the best version of themselves. The idea that they are working their ways to provide therapeutic reliefs and remedies for the benefit of others is part of how they identify themselves as Psychology students.

Furthermore, the roles of Psychology students is the next step. Based on the analysis of the textual and visual data provided, more than half of the data touch upon the issue. Visually, they were best represented in pictorial data of pictures of text books, piles of assignments, laptops and other gadgets used to work on projects, scenes of group works as well as sites or locations where group works took place.

The same message is represented in textual data both in photo captions and personal reflections - using the words such as 'projects' 'assignments, 'demands,' 'exhaustion' and 'frustration.' Yet there are also stories of personal and collective victories of 'excitement' and 'resilience.'

The essence that building academic social identity as a Psychology students is indeed a demanding task seems to be well-understood among the research subjects-participants. Acceptance on such taxing uphill journey is smoothened and facilitated by selfcare and peer supports - which seems to be pivotal on the establishment of their academic social identity. In deeper analysis, by comparing the layer of understanding personal reasons of choosing Psychology and understanding the roles of Psychology students, it seems that the extra demands they face are due to the following fact. Not only do they face the challenge of mastering the discipline themselves, but also they deal with the necessity of resolving with their personal issue - whatever they might be. 
The final step in their process of establishing their academic social identity is represented by their understanding of the roles of Psychology students in UPJ. This is best represented by the fact that one research subjects-participants deliberately chose this moment of accreditation as part of her academic social identity.

It should be taken into consideration that one of the key milestones of UPJ is the moment when the university received grade B (excellent) its accreditation for both department-level for all 10 as well as university level in in 2017-2018. One research subjects-participants selected herself standing in front of a flower wall to celebrate this moment, with photo caption and personal reflection of 'pride' and 'touched.'

These visual and textual data show that this individual identified with the academic institution and/or subject area - as 'technical' as accreditation into her personal victory she cherished during the time she spends throughout their educational process.

Limitation of this preliminary study is that it refrains from pursuing the comparative studies of similar qualitative queries of students from other departments - Civil Engineering or Informatics, to take the issues to the extreme. Envisioning that students of Civil Engineering establish their academic social identity because they wish to fix the roof or the pillar construction of their own residence, or students choose Informatics because they would like to improve their computer hardware and software at their own home would considerably be far-fetched.

Based on the limitation of this research, hence it would be interesting to investigate the same questions on different research subjects. Future direction would be opening up doors for further investigation to the process of adopting the trajectory of academic institution as an organization into the personal stories of academic social identity. It is recommended to pursue these avenues for other research in the future.

\section{CONCLUSSION}

This article started with seemingly a simple question: what does being a student of Psychology in Universitas Pembangunan Jaya means to you?

It is concluded that the answers to this question is far from simple. The journey of establishing academic social identity goes as far as five layers of understanding the meaning making process regarding (1) what Psychology is, (2) personal reasons for choosing Psychology, followed by (3) their social reasons to do so, to only be exposed to the seemingly to be the most painstaking layer of all, which is (4) understanding the roles as psychology students - to finally be resumed in the stage of (5) understanding their roles as Psychology Students in UPJ.

Indeed, there are caveats in examining the findings. Even though the researcher had secured their consents and allow them to articulate their personal expression as it is, it should be taken into consideration that the brutal struggle might be presented as socially desirable. Moreover, as it is already touched upon in the Discussion section, it would be interesting to conduct comparative studies with students from different departments, and to pursue more on how the development of academic social identity is influenced by organizational achievement.

To conclude, our identity - academic social identity included - and its development are neverending process. Hence the journey to find answers to a question of: "what does this - whatever 'this' might be - means to you" should always continue.

\section{ACKNOWLEDGEMENT}

The author would like to express her gratitude to all students of Qualitative Research Method who participate in this research: Athaya Dwinda Zakiah, Dinda Ayu Dwi Innesia, Anugrah Permata Sari, Clara Triana Saragih, Irene Miramis Asmara, Karina Rahayu, Gabrialle Angela Neve, Mellisa Octav Mariana, Naila Diyaul Aulia, Ardana Fanesia Sylsye, Citra Ananda Putri, Dwi Agustina Sacadipura, Dhaniya Putri Rossanti, Fauziah Nur Fazrina, Jihan Naziha, Juli Sarah Harahap, Laila Midori, Muhammad Rizky, Nadhine Syahzan, Nadira Ayu Kusumastuti, Nanda Novira, Zevica Rafisna, Zahran Rizky Salahudin, Yunita Fitriani, Nurlaela Rizkianti, Safira Prabandani Kusumastuti, Rasyifa Faradiba, Nurul Indah Ramadhanti, Jihan Fahera, Syifa Alya Muthiah, Shafira Qonita Kairina, Erisca Melia Safitri and Shafa Saprila.

\section{REFERENCES}

Barnet, R. (2006). Being and becoming: a student trajectory. International journal of lifelong education. 15, 2, 72-84. https://doi.org/10.1080/0260137960150202

Bliuic, A., Ellis, R.A., Goodyear, P. \& Hendres, D.M. (2011). Understanding student learning in context: Relationships between university students' social identity, approaches to learning, and academic performance. European Journal of Education 26, 417-433.

Bliuic, A., Goodyear, P. \& Ellis, R.A. (2017). The role of students' social identities in fostering high-quality learning in higher education. In Mavor, K.I, Platow, M.J \& Bizumic, B. (editors). Self and social identity in educational context. New York: Routledge.

Damono, S.J., Hardianto, H. \& Mardiyanto, H. (1996). Mempertimbangkan sastra Jawa. Semarang: Yayasan Adhigama.

Eatough, V. \& Smith, J.A. (2017). Interpretative phenomenology analysis. In Willig, C. \& StaintonRogers, W. (editors). Handbook of Qualitative Psychology. $2^{\text {nd }}$ edition. London: Sage.

Geenaway, K., Amiot, C.E., Louis, W.R. \& Bentley, S.V. (2017). The role of psychological need satisfaction in promoting student identification. In Mavor, K.I, Platow, M.J \& Bizumic, B. (editors). Self and social identity in educational context. New York: Routledge.

Henderson, H., Bathmaker, A., \& Stevenson, J. (2018) Introduction: Why possible selves and higher 
education? In Henderson, H., Stevenson, J. \& Bathmaker, A. (editors). Possible selves and higher education: New interdisciplinary insights. Research into Higher Education. New York: Routledge.

Himpunan Psikologi Indonesia (HIMPSI) (2010). Kode Etik Psikologi Indonesia. Jakarta: HIMPSI.

Maunder, R. et. al. (2013). Listening to student voices: Student researchers exploring undergraduate experiences of university transition. Higher education, 66, 139-152.

Mathikithel, M. \& Wood, L. (2019). Youth as participatory action researchers: Exploring how to make school a more enabling space. Educational research for social change. 8, 2, 77-95.

McGeough, J. (2017). Transition into higher education : Is the development of an academic social identity in psychology students important to achievement? Doctoral thesis. Liverpool John Moores University.

Mirra, N., Garcia, A. \& Morrell, E. (2016). Doing youth participatory action research: Transforming inquiry with researchers, educators and students. New York: Routledge.
Palibroda, B. et. al. (2009). A practical guide to photovoice: Sharing pictures, telling stories and changing communities. Winnipeg: Prairie Women's Health Center of Excellence.

Permana, R. et. al. (2017). Gambaran krisis psikologis mahasiswa tingkat pertama program sarjana Universitas Islam Bandung. Schema (Journal of Psychological Research) 3, 2, 92-103.

Sari, N., Tarsono, Kurniadewi, E. (2016). Pengaruh status identitas terhadap orientasi masa depan area pekerjaan. Psympathic: Jurnal Ilmiah Psikologi 3, 1, 121-138.

Shawn, E. (1999). A guide to the qualitative research process: Evidence from a small firm study. Qualitative Market Research: An International Journal 2, 2, 1-12.

Smyth, L., Mavor, K.I., Platow, M.J. \& Grace, D. M. (2017). Understanding social identity in education: the modifying role of perceived norms. In Mavor, K.I, Platow, M.J \& Bizumic, B. (editors). Self and social identity in educational context. New York: Routledge. 